R.H. Searle \& D. Skinner (Eds.) Trust and Human Resource Management, Edward Elgar: Cheltenham, UK.

\title{
Chapter 9:
}

\section{Career development, progression and trust}

Author:

Dr. Jonathan R. Crawshaw

Work and Organisational Psychology Group

Aston Business School, Aston University

Aston Triangle, Birmingham, B4 7ET

Telephone: $+44(0) 1212043130$

Email: j.r.crawshaw2@aston.ac.uk 


\section{Introduction}

The aim of this chapter is to explore in more detail the development of careerist orientated employees. In particular, the focus is on the roles played by trust in the employment relationship and (in)effective organisational career management (OCM), where OCM refers to the policies and practices developed by an employer to improve the career effectiveness and success of their employees (see Orpen, 1998). Careerist orientation is defined as, 'the propensity to pursue career advancement through nonperformance-based means' (Feldman \& Weitz, 1991, p. 237). Careerists believe that career advancement and progression in organisations is at best difficult, and at worst impossible, through hard work, competence and high performance alone (Feldman, 1985; Orpen, 1998). Instead careerists view impression management, politicking, deceit and the promotion of personal interests over those of their employer as the essential strategies for individual career progression and advancement in the contemporary employment relationship (for a review, see Feldman \& Weitz, 1991).

Such self-serving and narcissistic (Lasch, 1979) attitudes to work and employment have been shown to hold significant implications for both employers and employees. For the employer, the individual career management and advancement strategies described above override any responsibilities and requirements the employee may have regarding their actual job role and position within the organisation. It becomes more important to look like you are an effective high performing employee, and to convince key organisational agents (line managers, mentors) of this, rather than actually performing consistently well in your job (Landen, 2003; Bolino, 1999; Chay \& Aryee, 1999). Research has largely confirmed these ideas, finding empirical support for the negative impact careerist orientation has 
on a number of important job and employer-focussed attitudes and behaviours including, job involvement, individual performance and organisational commitment (e.g. Chay \& Aryee, 1999).

Such impression management and politicking strategies may also lead careerists to make short-term and risky decisions. Although such behaviours may, on the surface, appear as impressive, radical and innovative (perhaps all positive traits in an employee and thus likely to get them earmarked for promotion and advancement), they may actually have serious and long term negative consequences for the employer and the organisation (Feldman \& Weitz, 1991; Thompson, Kirkham \& Dixon, 1985). We may all be able to cite examples of the apparent 'high-fliers' that advance quickly through our organisation's ranks whilst leaving chaos and conflict behind them in their previous roles, departments, functions and/or work groups.

For the employee, careerism seems to work; at least on some level. Of the limited research that exists, evidence suggests that careerists do, on the whole, get promoted more and earn more money than non-careerists (see Westphal \& Stern, 2006; Judge \& Bretz, 1994; Feldman \& Klich, 1992); but at what long-term cost to them and their career? Thompson et al. (1985) suggest that promotion into more senior positions on the back of image and impressions rather than any substantial ability or skills may leave the individual out of his or her depth in their new role. Failure, and the subsequent fall from such senior and high responsibility roles, may be hard to recover from affecting seriously one's career going forward. Peers and supervisors may also resent being used and manipulated for personal gain thus making it increasingly difficult for the careerist to form future alliances and effective working relationships with colleagues. Such relative isolation may therefore 
ultimately affect their ability to function effectively in their new more senior roles (Feldman and Weitz, 1991).

\section{Careerism and the changing psychological contract}

The idea of the careerist employee is not new (see Lasch, 1979; Feldman, 1985), although there appears to be mounting evidence to suggest that continuing changes to the employment relationship are making it as relevant an issue for employers today as ever before (e.g. Landon, 2003). A substantial amount of research has placed concerns of careerism firmly in the context of continuing changes to the psychological contract (e.g. Feldman \& Weitz, 1991). The psychological contract refers to promises, both implied and explicit, that exist between two or more parties in the employment relationship (Rousseau, 1995). Such promises are said to emerge from an individual's observations and experiences in relation to norms of organisational and interpersonal behaviour (Sparrow, 1996).

Viewing the employment relationship from the perspective of a psychological contract positions the workplace as an arena for an ongoing negotiated exchange between employer and employee (Rousseau, 1995). It assumes that to elicit, from employees, the levels of commitment and performance needed for organisational survival and prosperity that this exchange must be relational rather than purely economic and instrumental (Newell, 1999). A social exchange model (Blau, 1964) is therefore proposed within the psychological contract literature, were the effective management and balancing of organisational and employee goals ensures the development and maintenance of trusting relations (see Atkinson, 2007; Aryee, Budhwar and Chen, 2002; Robinson, 1996; Herriot, 1992). 
Trust is therefore viewed as the explanatory factor or 'glue' that binds the employment relationship together becoming a central focus of research into the effects and effectiveness of a wide variety of people management and human resource management (HRM) interventions implemented by employers (e.g. Tzafrir \& Gur, 2007; Tzafrir, 2005; Tzafrir, Harel, Baruch \& Dolan, 2003; Zeffane and Connell, 2003). In line with this wider body HRM research social exchange theory, and as such the notion of the psychological contract and trust in the employment relationship, has also dominated empirical and theoretical work into the nature of organisational careers and the effectiveness of employers OCM policies and practices (for reviews see Arnold, 2001; Newell, 1999). In short, effective OCM matters because on receipt of desirable and expected career development opportunities, an individual's trust in management is maintained, thus leading the employee to reciprocate through more positive work and organisation-directed attitudes, behaviours and efforts (e.g. Eby, Allen \& Brinley, 2005; Sturges, Conway, Guest \& Liefooghe, 2005; Blau, Merriman, Tatum \& Rudmann, 2001; Chay \& Aryee, 1999).

Early career models tend to assume an individual would experience lifetime employment with a single employer; regular development opportunities and long term job security (see Schien, 1971). In exchange for this, employees would give their loyalty to one firm and their affective commitment to achieving its objectives (see Rousseau, 1995). Within such a paternalistic, long-term psychological contract one's career progression and development is provided for, and protected by, one's employer. Trust in the employment relationship is therefore maintained by effective OCM practices that focus on delivering long term job security and lifetime employment. Strong and transparent internal labour markets and career paths, effective and fair long term succession planning, and access to regular promotional 
opportunities are examples of OCM interventions and practices that may uphold such a paternalistic psychological contract (Baruch, 2004). However, where these are perceived by employees as absent or ineffective, the career-related bargain is broken and the negative consequences for employee attitudes and behaviours, such as careerism, are increased as trust in the employment relationship is lost.

For many authors this breaching of the career bargain has been the pattern for countless employees over the last few decades (Cappelli, 1999; Herriot \& Pemberton, 1995; 1997). Boom and bust economic cycles continue to lead to regular and frequent rounds of large-scale redundancy and downsizing in many sectors of employment. More and more individuals are suffering at least one and maybe more experiences of redundancy and lay-off, thus naturally impacting significantly on their perceptions of job security. Research around the so-called 'survivor syndrome' highlights the potential negative implications for job security and loyalty even for those lucky enough to survive such rounds of redundancy (Sahdev, 2004; Kets de Vries \& Balazs, 1997).

Within this challenging economic climate flexibility has become the key watchword of management and employers. The leaner and flatter organisational structures associated with more flexible employment strategies have led to increasing numbers of employees experiencing career plateauing, or stalling, earlier in their career as vertical promotional opportunities become more limited (see Arnold, 2001). This drive for flexibility has also led to a substantial growth in the use of non-standard employment relations such as part-time, temporary, agency and contingent work (see Kalleberg, 2000). Such alternative work arrangements (Sherer, 1996) build flexibility into the organization by allowing management greater freedom to expand and contract the workforce quickly to meet market demand. For the growing number of employees 
experiencing such forms of employment contract the notion of long-term job security and loyalty in the employment relationship is potentially meaningless (Cappelli, 2000; 1999). Indeed, there is growing research evidence highlighting the career-related inequities experienced by part-time and temporary employees including higher levels of employment and income insecurity (Weathers, 2001), limited support for continuous professional development and career development (Bryson \& Blackwell, 2006) and increased propensity for dropping out of the labour market altogether (Gash, 2008; O’Reilly \& Bothfeld, 2002).

Trust in the organisation, therefore, needs to be rebuilt, or for those who never experienced a more paternalistic support from their employer, upheld, through the development and implementation of different strategies of OCM that reflect this new transactional, short term psychological contract and career reality (Aryee \& Chen, 2004; Herriot \& Pemberton, 1997). Herriot and Pemberton's 'new deal' suggests that trust may be maintained by a re-focussing of OCM strategies on the promotion of an individual's employability (see also, Newell, 1999; Herriot, 1992). OCM practices must therefore involve opportunities for developing transferable skills with interventions such as career counselling and support for career planning, and access to relevant training, education and qualifications commonly cited as facilitating as such (Baruch, 2004; Baruch and Peiperl, 2000). By providing employees with support for career exploration, planning and change which help develop essential and relevant transferable skills (thus providing employability security) employers may continue to elicit the kinds of high levels of employee citizenship, commitment and performance (albeit perhaps over a shorter relationship time-span) required to survive and prosper into the future (e.g. Cameron, Freeman \& Mishra, 1991). Such strategies should also help to suppress and reduce the emergence of more negative career-related attitudes 
and behaviours in their employees, such as careerist orientations to work (e.g. Aryee \& Chen, 2004)

Empirical research that tests for these relationships between effective OCM practices, trust and important career-related outcomes such as careerist orientation is however still limited. Two of the most recent and relevant of these studies have been carried out in very specific non-Western contexts of Singapore (Chay \& Aryee, 1999) and China (Aryee \& Chen, 2004), with mixed findings. Chay and Aryee's study of 249 Singaporean workers found little evidence to suggest that providing career growth opportunities would moderate the negative impact of careerist orientation on turnover, job involvement and commitment. Although, trust was not specifically investigated, from this study it appears that the provision of career growth opportunities may have little impact on the reduced lack of trust in the employment relationship that exists for a careerist.

However, the more recent study by Aryee and Chen (2004) of 149 employees of a Chinese household appliance manufacturer reported a significant negative relationship between an individual's perceptions of career growth opportunities and careerist orientations to work. They posit that many Chinese organisations are currently undergoing the restructuring and downsizing processes experienced by Western organisations through the latter part for the 20th century and for many employees a more transactional, short term psychological contract is becoming the norm. Within this context, their research presented full support for a model where trust in management mediates the relationship between employee perceptions of their career growth opportunities and careerist orientations to work. Given the limited number of studies, the culturally specific nature of them and the mixed findings reported it is essential that more empirical research is carried out, in different national 
and organisational contexts, so that we may develop a better understanding of the nature of these relationships.

\section{The development of careerist orientation - does trust always matter?}

A further limitation of psychological contract literature, and more generally social exchange theory, is that they appear to give very little regard to wider contextual factors that may influence the nature of the exchange relationship, and assume that the development and maintenance of trust is always an important antecedent of employee attitudes and behaviours (see Kramer \& Tyler, 1996, Robinson, 1996, Robinson \& Rousseau, 1994). But is this the case? Are there contextual or contingent factors that may moderate the effects of trust? The focus of this chapter is on distributive justice and organisational commitment as potential moderators of the trust-outcomes relationship.

The interaction effects of distributive justice and trust

Around a decade or so ago Brockner and Wiesenfeld (1996) presented a substantial meta-analysis highlighting a consistent and robust interaction effect between perceptions of distributive justice and procedural justice across a variety of experimental and applied studies with a range of different outcome measures. Distributive justice refers to one's perceptions of fairness regarding the allocation of certain valued resources or rewards, and procedural justice concerns the fairness of the decision-making making processes used to decide these allocations (for a review see Colquitt et al., 2001). Their studies tended to show that procedural justice 
mattered more as a predictor of an employee's attitudes and behaviours when they reported low levels (rather than high levels) of distributive justice (see also, Folger, 1986). This interaction is explained through a model of cognitive sense-making. In short, when people feel that they have been treated unfairly (distributive injustice) they seek explanations by exploring the fairness of the procedures used to decide these outcomes. Conversely, when they feel that they have been treated fairly (distributive justice) no such sense-making is required thus reducing the importance of procedural justice when determining one's reactions to the decision (for a review, see Cropanzano and Greenberg, 1997)

At the same time, however, researchers began to propose a slightly different interaction effect between distributive justice and trust (Brockner \& Siegel, 1996). This work contended that trust and not procedural justice was important to individuals. Procedural justice may still be relevant but only as a proxy, or heuristic, for making judgements regarding the trustworthiness of their employer (see Brockner, Ackerman \& Fairchild, 1998_2001). Consequently, researchers where charged to refocus on exploring the moderating effect of distributive justice on the trustoutcomes relationship. To this end it was argued that trust may matter more as a predictor of outcomes when perceptions of distributive justice are low, rather than high (Brockner \& Siegel, 1996). When the distribution of resources and rewards appears to be inequitable (and thus unfair) it is proposed that one seeks to make sense of this situation and this is done by reaching a decision on how trustworthy the system is that has made this decision. Trust, thus, becomes more important when making decisions regarding your subsequent efforts and reactions to the system. If the system is viewed as trustworthy then this will buffer against potential negative impact on the individual's attitudes and behaviours of low distributive justice (see Brockner et al., 
1998_2001). In contrast, if one perceives resources and rewards to be distributed equitably no further information is needed regarding the appropriateness of the system; thus, here trust thus matters less in predicting an individual's reaction. A collection of empirical studies from Brockner et al. (1997) provided consistent support for these proposals.

Crawshaw and Brodbeck (in press) tested for these interaction effects between trust and distributive justice when predicting employee careerist orientation to work. They hypothesised that the negative relationship between trust and careerist orientation would be stronger when an employee viewed their career development opportunities as inequitable and unfair. If the system is perceived to be trustworthy, and the current inequities in one's career development opportunities can be put down to perhaps a one-off decision or a single specific individual, trust in the system should buffer the potential negative effects on careerism that may be caused by the perceived inequity.

Interestingly, they reported a significant interaction effect between trust and distributive justice on careerist orientation, but not in the predicted direction. It appears that the negative relationship between trust and careerism is stronger not when perceptions of distributive justice are low but when they are high. Trust therefore matters more when employees view their career development opportunities as fair and equitable. Conversely, when career development opportunities are viewed as unfair it would seem that the trustworthiness of the system has little influence over the emergence, or not, of careerist orientated employees. 
The interaction effects of organisational commitment and trust

To date, there has only been one study that has investigated the potential for moderators of the trust - careerism relationship. We suggest and present evidence of organisational commitment as a further moderator of this relationship. Most previous work has tended to focus on studying careerism as an antecedent of organisational commitment, that is, employees who report more careerist orientation towards work will exhibit less organisational commitment than those reporting less careerist orientation (e.g. Chay \& Aryee, 1999). However, commitment has also been shown to act as a moderator of employee reactions to organisational decision-making. For example, Brockner, Tyler and Cooperschneider (1992) found support for commitment effecting people's reactions to the perceived unfairness of layoff decisions. Those employees who reported higher organisational commitment were hit harder by the perceived unfairness of layoff decisions than those who reported low prior organisational commitment (Brockner et al., 1992). In related research Kwong and Leung (2001) demonstrated that the distributive justice by procedural justice interaction described earlier was moderated by organisational commitment. It appears that procedural justice may only buffer the negative implications of low distributive justice when an employee's commitment to, or identification with (DeCremer, 2005), their employer is high.

Evidence suggests, therefore, that one's identification with, or commitment to, their employer strongly influences how they react to decisions made by them. Building upon this existing research, therefore, the present author argues that trust may only be an important predictor of careerist orientation when an individual values and indentifies with the organisation he/she currently works for. When organisational 
commitment is low, building trust in the employment relationship, through effective OCM policies and practices, may have little impact on an individual's overall careerist attitudes and behaviours towards work.

Let us take the example of early career graduates. Extant research has shown many within this cohort of employees to be highly careerist (e.g. Sturges et al., 2002; Sturges, Guest \& Mackenzie Davey, 2000; Viney, Adamson \& Doherty, 1997; Dougherty, Dreher \& Whitely, 1993; Rousseau, 1990), commonly using their first appointments/jobs as strategic 'stepping stones' to more desirable future employment positions and opportunities (Thompson, Kirkham \& Dixon, 1985). Such careerism, however, is not necessarily due to a lack of trust in their current employer to look after their career aspirations. Instead, this may be a natural reaction to an increasingly competitive external labour market. Graduates are aware that their employability and future career success are more and more dependent on the attainment of essential transferable work experiences and, as a result, may seek to attain these experiences anywhere; even in organisations, industries and sectors that they have no intention of ultimately pursuing their future careers (for examples see Robinson \& Rousseau, 1994; Rousseau, 1990).

For such individuals, the relationship with employers during the very early stages of their career is instrumental to the extreme - a 'stepping stone' - with no direct commitment at all to the organisation's objectives only their own career goals. It is proposed that within such a context, trust in the employment relationship becomes much less important to the individual and thus less likely to predict careerist orientation. Indeed, graduates (particularly those found on specific graduate management development programmes) are commonly given greater access (than non-graduates) to highly valued career development and training opportunities, thus 
one would believe developing a high trust relationship with their employer. Yet turnover in this employee group continues to be extremely high (Bedingfield, 2005; Dougherty, Dreher and Whitely, 1993). It may be that many of these graduates never had any intention of furthering their career with this employer and thus irrespective of how well they have been treated, and what career development/training opportunities they have been given, their single goal is to get access to as many career development opportunities as possible so that they may secure a move into their 'dream job'. Their lack of commitment to this employer thus potentially moderates the role of trust in the employment relationship as a predictor of careerist orientation.

\section{Empirical evidence - The case of BankCo}

The aim of this study was to extend current empirical research by testing for the relationships between employee perceptions of their career development opportunities, their trust in management and careerist orientation. More specifically, how trust mediates the negative association between career development opportunities and careerist orientation and how organisational commitment moderates the trust - careerism relationship.

The research was carried out in a large UK financial institution - from now on referred to as BankCo. In 2002, a self-report questionnaire was distributed to a random stratified sample of 1100 BankCo employees from all functions and levels of the organisation. The questionnaires, along with prepaid return addressed envelopes, were distributed via the internal mail system and returned anonymously. Three hundred and twenty five (325) questionnaires were fully completed and returned which gave a final usable response rate of 30 per cent. Of these respondents, 41.5 per 
cent were in management positions, 68.3 per cent were female, 92.6 per cent were of white UK ethnic origin and their average age and length of service were 34.9 years and 8.9 years respectively. These figures reflected closely the demographic profile of the wider employee population $(\mathrm{N}=1100)$ and thus promoted confidence in the representative nature of this sample.

Measures

Careerist-orientation to work was measured using a shortened five-item version of a scale developed by Feldman and Weitz (1991). Respondents were asked how much they agreed/disagreed with each statement and asked to respond along five-point Likert scale. An example item was, "In the final analysis, what's best for me in my career is not going to be consistent with what's in the organisation's best interests". A Cronbach alpha score of 0.68 was deemed to promote a moderate yet acceptable level of reliability. Indeed, the alpha reliability score closely reflected those commonly reported in other previous studies using this scale (see Aryee and Chen 2004).

Satisfaction with career development opportunities was measured using twoitems, "I am satisfied with my current career development opportunities in this company" and "The career development opportunities I am currently receiving in this company are acceptable". Participants were directed to respond to each statement along a five-point Likert scale. A Cronbach alpha score of 0.95 promoted the reliability of this measure.

Trust in management was measured using a three-item scale used by Brockner et al. (1997). This measure was developed to tap into an individual's overall perceptions of trust in organisational authorities. Consequently, trust items are 
directed at both one's direct supervisor and 'management' in more general terms. The following example items reflect this focus on both systemic and interpersonal forms of trust to form an overall measure of trust, "I can usually trust my career development supervisor to do what is good for me"; "Management can be trusted to make decisions that are also good for me". Respondents were asked how much they agreed/disagreed with each statement and asked to respond to each item along a fourpoint Likert scale. A Cronbach alpha score of 0.87 promoted confidence in the reliability of the scale.

Organisational commitment was measured using an eight-item scale developed by Meyer and Allen (1984). Participants were asked to respond along a five-point Likert scale how much they agreed/disagreed with each statement. An example item is, "I do not feel 'emotionally attached' to this organisation." A Cronbach alpha score of 0.87 promoted the reliability and internal stability of this measure.

\section{Findings}

Analysis was via enter-method hierarchical regression on SPSS version 11. In line with previous research (e.g. Sutherland \& Davidson, 1996; Wentling, 1996; Cascio, 1995), gender, ethnicity, age, length of service and job level were all controlled for in the analysis. Correlations, means and standard deviations of all tested independent and dependant variables are presented in Table 1 below. 
As predicted, an employee's satisfaction with their career development opportunities was found to be positively related to their trust in management $(\beta=.67$, $p=.000)$ and negatively related to careerist orientation $(\beta=-.33, p=.000)$ (see Table 2).

\section{INSERT TABLE 2 ABOUT HERE}

Moreover, this negative relationship between an employee's satisfaction with their career development opportunities and careerist orientation was found to be mediated by their trust in management $(\beta=-.20, p=.005)$ (see Table 3$)$. The Sobel test confirmed that the drop in the beta weight of career development satisfaction when trust was entered into the regression equation is statistically significant (Sobel test statistic $=3.94, p=.000)$.

\section{INSERT TABLE 3 ABOUT HERE}

Finally, organisational commitment was found to moderate the relationship between trust and careerist orientation $(\beta=-.13, p=.013)$ (see Table 4). This interaction effect was as predicted with trust more strongly associated with careerist orientation when an employee's organisational commitment is high, rather than low (see Figure 1). It appears that trust only matters as a predictor of careerist orientation when an individual's commitment to their current employer is high.

INSERT TABLE 4 ABOUT HERE

INSERT FIGURE 1 ABOUT HERE 


\section{Implications for Theory and Practice}

The aim of this chapter was to investigate the role of trust in management as a mediator of employee reactions to the career development opportunities provided by their employer. In particular, the focus was on the role trust plays in the emergence of careerist orientated employees. In addition, we wanted to extend our understanding of these relationships by exploring and discussing the conditions under which trust may matter more when predicting careerist orientations to work.

Having reviewed the literature, and presented the findings above, trust is further confirmed as a key mediator of the relationship between an individual's satisfaction with their career development opportunities and careerist orientations to work. It appears that when individuals are satisfied with their career development opportunities their careerist orientations are reduced because their trust in the employment relationship is upheld and maintained. By providing satisfying career development opportunities, through the development of effective OCM policies and practices, employers may therefore reduce the emergence of the extreme, and potentially harmful (to both employer and individual), individual career management behaviours associated with careerist orientations to work. These findings confirm social exchange theory as a good framework for understanding employee reactions to OCM practices (e.g. Sturges et al., 2005) and those findings of recent studies into the antecedents of careerist orientation to work (e.g. Aryee and Chen, 2004).

Recent research has however also begun to explore potential moderators of this relationship. For example, Crawshaw and Brodbeck (in press) identified support for distributive justice as a moderator of the relationship between trust and careerist orientation, where trust mattered more when distributive justice was high rather than 
low. They concluded that when an employee views their career development opportunities as unfair, the development of trust in the employment relationship may have little impact on careerism. However, when career development opportunities are perceived to be fair maintaining high trust relations appears to accentuate the positive implications for reduced careerist orientation.

The current chapter builds on these earlier findings by exploring the notion that trust may matter more or less to employees dependent on their identification with, and commitment to, the employer. When organisational commitment is low, trust appears to matter little as a predictor of careerism. However, when organisational commitment is high, building trust in the employment relationship by providing employees with satisfying career development opportunities seems to be central to the reduction of employees' careerist orientation. One's identification with, or commitment to, their employer thus seems to have a significant impact upon the importance of trust as a predictor of employee reactions to OCM policies and practices.

In light of these discussions and findings, a number of important implications for employers and managers are indicated. Effective OCM policies and practices and career development interventions are essential if employers are to build trust in the employment relationship and reduce the potential for employees developing careerist attitudes and behaviours towards work. If individuals are dissatisfied with the career development opportunities afforded them by their employer it is more likely that they will begin to take matters into their own hands and initiate the extreme individual career management behaviours associated with careerism.

These policies need to provide employees with a voice and some influence over the direction of their career, with specific interventions to support this. Examples 
may include the use of development centres, a career counselling service or simply a specific part of the employee annual appraisal process given over to personal and career development planning. In smaller organisations where such interventions may not be affordable or feasible such OCM practices may just take the form of more regular and informal conversations with one's supervisor/line manager.

However, developing and implementing effective OCM policies and practices is not sufficient on its own to avoid the emergence of careerist orientated employees. It is also essential that the system distributes career development opportunities in a fair and equitable way. For most employees, decisions regarding access to career development opportunities such as careers advice/counselling; mentoring schemes, secondments and training interventions are made by their direct line manager or supervisor (Crawshaw, 2006). It is important, therefore, that these key agents in an individual's career are fully trained in this role and are fully aware of the equity sensitivity (Feldman \& Weitz, 1991) of employees when it comes to their career management.

Finally, employers must also focus on recruiting committed employees and not those who are just interested in using the job and company as a 'stepping stone' to something more highly valued. More employer-focussed selection techniques such as, tailored assessment centres may aid in the recruitment of individuals who are more committed to the values and goals of the organisation (Woodruffe, 2007). These findings challenge the value and utility of 'fast-track' schemes targeted at high potentials which appear to attract and promote the kinds of extreme and unhealthy careerism (Kirkham et al., 1985). 


\section{Future Directions of Research}

There are a number of limitations to the current research. Many of these studies are based on cross sectional designs and self-report data. If we are to develop further our knowledge and understanding of these relationships future studies need to incorporate more longitudinal research designs and, where possible, more objective sources of data. Work is also needed in new organisational and national contexts if we are to fully understand the transferability and generalisability of these findings into different cultural settings.

Researchers may also begin to explore the potential for further moderators of the trust - careerist orientation relationship. Evidence is now growing that organisational commitment and distributive justice are potentially important moderators of the importance of trust in the employment relationship, but there also seems to be great potential in looking at a variety of individual differences and personality variables. Some work has already highlighted the strong links between personality and trust (Mooradian, Renzl, \& Matzler, 2006) and personality and trustrelated constructs such as citizenship (Moorman \& Blakely, 1995) so it may follow that trust matters more in the employment relationship for different personality types? Are there personality types that are associated more strongly with careerist attitudes and behaviours to work? There are certainly many interesting avenues for further research and it is hoped that this chapter has provided a useful start point for researchers to investigate more closely the complex role of trust in the employment relationship and its function in explaining employee reactions to various career and career management-related policies, practices and interventions. 


\section{Acknowledgements}

The author would like to thank Prof. Felix Brodbeck (Ludwig-Maximilians University) and Prof. Anne-Marie Greene (Warwick University) for their invaluable, and immeasurable, contributions to the ideas and research that inform this chapter.

\section{References}

Arnold, John (2001), 'Careers and career management', in Neil Anderson, Deniz Ones, Handan Sinangil and Chockalingam Viswesvaran (eds.), Handbook of Industrial, Work and Organizational Psychology, vol. 2, London: Sage, pp. 115-132. Aryee, S, Budhwar, P. and Z. X. Chen (2002), 'Trust as a mediator of the relationship between organizational justice and work outcomes: test of a social exchange model', Journal of Organizational Behavior, 23 (3), 267-285.

Aryee, S. and Z. X. Chen (2004), 'Countering the trend towards a careerist orientation in the age of downsizing: test of a social exchange model', Journal of Business Research, 57 (4), 321-328.

Atkinson, C. (2007), 'Trust and the psychological contract', Employee Relations, 29 (3), 227-246.

Baruch, Yahuda (2004), Managing Careers: Theory and Practice, Harlow: FT Prentice Hall.

Baruch, Y. and M. Peiperl (2000), 'Career management practices: An empirical survey and implications', Human Resource Management, 39 (4), 347-366.

Bedingfield, C. (2005), 'Transforming the ROI of your graduate scheme', Industrial and Commercial Training, 37 (4), 199-203. 
Blau, G., Merriman, K., Tatum, D. S. and S. V. Rudmann (2001), 'Antecedents and consequences of basic versus career enrichment benefit satisfaction', Journal of Organizational Behavior, 22 (6), 669-688.

Blau, Peter (1964) Exchange and power in social life, New York: Wiley.

Bolino, M. (1999), 'Citizenship and impression management Academy of Management Review: good soldiers or good actors?' 24 (1), 82-98.

Brockner, Joel, Ackerman, Grant, and Gregory Fairchild (2001), 'When do elements of procedural fairness make a difference? A classification of moderating differences', in Greenberg, J. and Cropanzano, R. (eds.), Advances in Organizational Justice, Stanford, CA: Stanford Books, pp. 179-212.

Brockner, Joel and Phyllis Siegel (1996), 'Understanding the interaction between procedural and distributive justice: the role of trust', in Roderick M. Kramer and Tom Tyler (eds.) Trust in Organizations: The Frontiers of Theory and Research (pp. 390413), London: Sage, pp. 390-413.

Brockner, J., Siegel, P. A., Daly, J. P., Tyler, T., and C. Martin (1997), 'When trust matters: The moderating effect of outcome favourability', Administrative Science Quarterly, 42 (3), 558-583.

Brockner, J., Tyler, T., and R. Cooperschneider (1992), 'the influence of prior commitment to an institution on reactions to perceived unfairness: The higher they are the harder they fall', Administrative Science Quarterly, 37 (2), 241-261.

Brockner, J. and B. Wiesenfeld, (1996), 'An integrative framework for explaining reactions to decisions: Interactive effects of outcomes and procedures', Psychological Bulletin, 120 (2), 189-208.

Bryson, C. and R. Blackwell (2006), Managing temporary workers in higher education: Still at the margin? Personnel Review, 35 (2), 207-224. 
Cameron, K., Freeman, S. and A. Mishra (1991), 'Best practice in white-collar downsizing: managing contradictions', Academy of Management Executive, 5 (1), 57 73.

Cappelli, P. (2000), 'Managing without commitment', Organizational Dynamics, 28 (4), 11-24.

Cappelli, Peter (1999), The New Deal at Work: Managing the Market-Driven Workforce, Boston: Harvard Business School Press.

Cascio, Wayne F. (1995) Managing Human Resources: Productivity, Quality of Work Life, Profits ( $4^{\text {th }}$ ed.), London: McGraw-Hill.

Chay, Y-W. and S. Aryee (1999), 'Potential moderating influence of career growth opportunities on careerist orientation and work attitudes: evidence of the protean career era in Singapore', Journal of Organizational Behavior, 20 (5), 613-623.

Colquitt, J. A., Conlon, D. E., Wesson, M. J., Porter, C. O. L. H., and K. Y. Ng (2001), 'Justice at the millennium: A meta-analytic review of 25 years of organizational justice research', Journal of Applied Psychology, 86 (3), 425-445.

Crawshaw, J. R. (2006), 'Justice source and justice content: evaluating the fairness of organisational career management practices', Human Resource Management Journal, 16 (1), 98-120.

Crawshaw, J. R. and F. C. Brodbeck (in press), 'Justice and trust as antecedents of careerist orientation', Personnel Review.

Cropanzano, Russell and Jerald Greenberg (1997) 'Progress in organizational justice: Tunnelling through the maze', in Cary Cooper and Ivan Robertson (eds.) International Review of Industrial and Organizational Psychology, vol. 12, Chichester: Wiley \& Sons Ltd, pp. 317-372. 
De Cremer, D. (2005), 'Procedural and distributive justice effects moderated by organizational identification', Journal of Managerial Psychology, 20 (1), 4-13.

Dougherty, T., Dreher, G. and W. Whitely (1993), 'The MBA as careerist: an analysis of early-career job change', Journal of Management, 19 (3), 535-548.

Eby, L. T., Allen, T. D. and A. Brinley (2005), 'A cross-level investigation of the relationship between career management practices and career-related attitudes', Group and Organization Management, 30 (6), 565-596.

Feldman, D. C. (1985), 'The new careerism: origins, tenants, and consequences', The Industrial - Organizational Psychologist, 22 (1), 39-44.

Feldman, Daniel C. and Nancy Klich (1992) 'Impression management and career strategies', in Robert Giacalone and Paul Rosenfeld (Eds.), Applied Impression Management, Newbury Park: Sage, pp. 67-80.

Feldman, D. C. and B. Weitz (1991), 'From the invisible hand to the gladhand: understanding a careerist orientation to work', Human Resource Management, 30 (2), 237-257.

Folger, Robert (1986), 'Rethinking equity theory: A referent cognitions model' in Hans W. Bierhoff, Ronald L. Cohen and Jerald Greenberg (eds.). Justice in social relations, New York: Plenum, pp. 145-162.

Gash, V. (2008) Bridge or trap? Temporary workers' transitions to unemployment and to the standard employment contract, European Sociological Review, 24 (5), 651668.

Herriot, Peter (1992), The Career Management Challenge: Balancing Individual and Organizational Needs, London: Sage.

Herriot, P. and C. Pemberton (1997), 'Facilitating new deals', Human Resource Management Journal, 7 (1), 45-56. 
Herriot, P. and C. Pemberton (1995), 'A new deal for middle managers', People Management, 1 (12), 32-34.

Judge, T. A. and R. D. Bretz (1994), 'Political influence behaviour and career success', Journal of Management, 20 (1), 43-65.

Kalleberg, A. L. (2000), 'Non-standard employment relations: part-time, temporary and contract work', Annual Review of Sociology, 26, 341-365.

Kets de Vries, M. and K. Balazs (1997), 'The downside of downsizing', Human Relations, 50 (1), 11-50.

Kramer, Roderick M. and Tom R. Tyler (eds) (1996) Trust in Organizations: The Frontiers of Theory and Research, London: Sage.

Kwong, J. Y. Y. and K. Leung (2001), 'A moderator of the interaction effect of procedural justice and outcome favorability: Importance of the relationship', Organizational Behavior and Human Decision Processes, 87 (2) 278-299.

Landon, M. (2003), 'Citizenship or careerism? Perceptions and impressions of goodness', Tamara: Journal of Critical Postmodern Organization Science, 2 (3), 1727.

Lasch, Christopher (1979) The Culture of Narcissism, New York: Warner Books.

Meyer, J. P. and N. J. Allen (1984), 'Testing the "side-bet theory" of organizational commitment: Some methodological considerations', Journal of Applied Psychology, 69 (3), 372-378.

Mooradian, T., Renzl, B., and K. Matzler (2006), 'Who trusts? Personality, trust and knowledge sharing', Management Learning, 37 (4), 523-540.

Moorman, R. H. and G. L. Blakely (1995), 'Individualism-collectivism as an individual difference predictor of organizational citizenship behaviour', Journal of Organizational Behavior, 16 (2), 127-142. 
Newell, Helen (1999), 'Managing careers', in Steven Bach and Keith Sisson (eds.), Personnel Management. Oxford: Blackwell, pp. 218-240.

O'Reilly, J. and S. Bothfeld (2002) 'What happens after working part time? Integration, maintenance or exclusionary transitions in Britain and western Germany', Cambridge Journal of Economics, 26, 409-439.

Orpen, C. (1998), 'Correlates of a careerist orientation to work', Psychological Reports, 82 (3), 1248-1250.

Robinson, S. L. (1996), 'Trust and breach of the psychological contract', Administrative Science Quarterly, 41 (4), 574-599.

Robinson, S. and D. Rousseau (1994), 'Violating the psychological contract: not the exception but the norm', Journal of Organizational Behavior, 15 (3), 245-259.

Rousseau, Denise (1995), Psychological Contracts in Organizations, London: Sage. Rousseau, D. (1990), 'New hire perceptions of their own and their employer's obligations: a study of psychological contracts', Journal of Organizational Behavior, $11(5), 389-400$.

Sahdev, K. (2004), 'Revisiting the survivor syndrome: The role of leadership in implementing downsizing', European Journal of Work and Organizational Psychology, 13 (2), 165-196.

Schein, E. (1971), 'The individual, the organization, and the career: A conceptual scheme', Journal of Applied Behavioural Science, 7 (4), 401-426.

Sherer, Peter (1996), 'Toward an understanding of the variety of work arrangements: the organization and labor relationship framework' in Cary L. Cooper and Denise M. Rousseau (eds.) Trends in Organizational Behavior 3, Chicheser: Wiley, pp. 99-122. Sturges, J., Conway, N., Guest, D. and A. Liefooghe (2005), 'Managing the career deal: the psychological contract as a framework for understanding career 
management, organizational commitment and work behaviour', Journal of Organizational Behavior, 26 (7), 821-838.

Sturges, J., Guest, D., Conway, N., and K. Mackenzie Davey (2002), 'A longitudinal study of the relationship between career management and organizational commitment among graduates in the first ten years at work', Journal of Organizational Behavior, $23(6), 731-748$.

Sturges, J., Guest, D. and K. Mackenzie Davey (2000), 'Who’s in charge? Graduates' attitudes to and experiences of career management and their relationship with organizational commitment', European Journal of Work and Organizational Psychology, 9 (3), 351-370.

Sutherland, V. and M. Davidson (1996), 'Managing diversity: Using an equal opportunities audit to maximise career potential and opportunities in a UK bank', European Journal of Work and Organizational Psychology, 5 (4), 559-582.

Thompson, P., Kirkham, K. and J. Dixon (1985), 'Warning: the fast track may be hazardous to organizational health', Organizational Dynamics, 13 (4), 21-33.

Tzafrir, S. S. (2005), 'The relationship between trust, HRM practices and firm performance', International Journal of Human Resource Management, 16 (9), 16001622.

Tzafrir, S. S. and A. B. A. Gur (2007), 'HRM practices and perceived service quality: the role of trust as a mediator', Research and practice in Human Resource Management, 15 (2), 1-20.

Tzafrir, S. S., Harel, G. H., Baruch, Y. and S. L. Dolan (2003), 'The consequences of emerging HRM practices for employees' trust in their managers', Personnel Review, $33(6), 628-647$. 
Viney, C., Adamson, S. and N. Doherty (1997), 'Paradoxes of fast-track career management', Personnel Review, 26 (3), 174-186.

Weathers, C. (2001) 'Changing white-collar workplaces and female temporary workers in Japan', Social Science Japan Journal, 4 (2), 201-218.

Wentling, R. M. (1996), 'A study of career development and aspirations of women in middle management', Human Resource Development Quarterly, 7 (3), 253-270.

Westphal, J. D. and I. Stern (2006), 'The other pathway to the boardroom: Interpersonal influence behavior as a substitute for elite credentials and majority status in obtaining board appointments', Administrative Science Quarterly, 51 (2), $169-204$.

Woodruffe, Charles (2007), Development and assessment centres: identifying and developing competence (4th ed), London: Human Assets.

Zeffane, R. and J. Connell (2003), 'Trust and HRM in the new millennium', International Journal of Human Resource Management, 14 (1), 3-11. 
Table 1: Means, standard deviations and inter-correlations

\begin{tabular}{lllllll}
\hline & $M$ & $S D$ & 1 & 2 & 3 & 4 \\
\hline 1. Career development & 3.27 & 1.19 & & & & \\
(CD) satisfaction & & & & & & \\
2. Trust & 2.81 & .63 & $.68^{* * *}$ & & & \\
3. Careerist orientation & 2.90 & .63 & $-.35^{* * *}$ & $-.35^{* * *}$ & & \\
4. Distributive justice & 2.89 & 1.24 & $.69^{* * *}$ & $.54^{* * *}$ & $-.34^{* * *}$ & \\
5. Organisational & 3.51 & .75 & $.44^{* * *}$ & $.48^{* * *}$ & $-.50^{* * *}$ & $.38^{* * *}$ \\
$\quad$ Commitment & & & & & &
\end{tabular}

Note: $* p<.05 * * p<.01 * * * p<.001$ 
Table 2: The relationship between career development opportunities and trust/careerist orientation

\begin{tabular}{cllclccc}
\hline & & \multicolumn{3}{c}{ Trust } & \multicolumn{3}{c}{ Careerist Orientation } \\
\hline Step & $\begin{array}{l}\text { Independent } \\
\text { Variables }\end{array}$ & $\beta$ & $\begin{array}{c}\mathrm{R}^{2} \\
\text { Change }\end{array}$ & $\begin{array}{l}\text { Sig. } \mathrm{R}^{2} \\
\text { Change }\end{array}$ & $\beta$ & $\begin{array}{c}\mathrm{R}^{2} \\
\text { Change }\end{array}$ & $\begin{array}{c}\text { Sig. } \mathrm{R}^{2} \\
\text { Change }\end{array}$ \\
\hline 1 & Gender & .05 & .06 & .001 & $-.14^{*}$ & .06 & .003 \\
& Age & .10 & & & -.12 & & \\
& Ethnicity & $-.22^{* * *}$ & & & $.13^{*}$ & & \\
& Tenure & -.07 & & & $.14^{*}$ & & \\
& Job level & -.06 & & & $-.16^{*}$ & & \\
2 & CD & $.67^{* * *}$ & .41 & .000 & $-.33^{* * *}$ & .10 & .000 \\
& satisfaction & & & & & & \\
\hline
\end{tabular}

Note: $* p<.05 * * p<.01 * * * p<.001$ 
Table 3: Trust as a mediator of the relationship between career development opportunities and careerist orientation

\begin{tabular}{cllcc}
\hline Step & Independent variables & $\beta$ & $\mathrm{R}^{2}$ Change & $\begin{array}{c}\text { Sig. } \mathrm{R}^{2} \\
\text { Change }\end{array}$ \\
\hline 1 & Gender & $-.14^{*}$ & .06 & .012 \\
& Age & -.12 & & \\
& Ethnicity & $.13^{*}$ & & \\
& Tenure & $.14^{*}$ & & .000 \\
& Job level & $-.16^{*}$ & & .005 \\
3 & CD satisfaction & $-.33^{* * *}$ & .10 & \\
& CD satisfaction & $-.19^{* *}$ & .02 & \\
& Trust & $-.20^{* *}$ & & \\
\hline Note: $* p<.05 * * p<.01 * * * p<.001$ & & &
\end{tabular}


Table 4: Trust and careerist orientation - the moderating role of organisational commitment

\begin{tabular}{|c|c|c|c|c|}
\hline Step & Independent variables & $\beta$ & Change in $\mathrm{R}^{2}$ & $\begin{array}{l}\text { Sig. } \mathrm{R}^{2} \\
\text { Change }\end{array}$ \\
\hline 1 & $\begin{array}{l}\text { Gender } \\
\text { Age } \\
\text { Ethnicity } \\
\text { Tenure } \\
\text { Job level }\end{array}$ & $\begin{array}{l}-.14^{*} \\
-.12 \\
.13^{*} \\
.14^{*} \\
-.16^{*}\end{array}$ & .06 & .012 \\
\hline 2 & CD satisfaction & $-.33 * * *$ & .10 & .000 \\
\hline 3 & $\begin{array}{l}\text { Org Commitment (OC) } \\
\text { Trust }\end{array}$ & $\begin{array}{l}-.41^{* * *} \\
-.06\end{array}$ & .13 & .000 \\
\hline 4 & OC $\times$ Trust & $-.13 * *$ & .02 & .013 \\
\hline
\end{tabular}

Note: $* p<.05 * * p<.01 * * * p<.001$ 
Figure 1: Organisational commitment (OC) by Trust Interaction

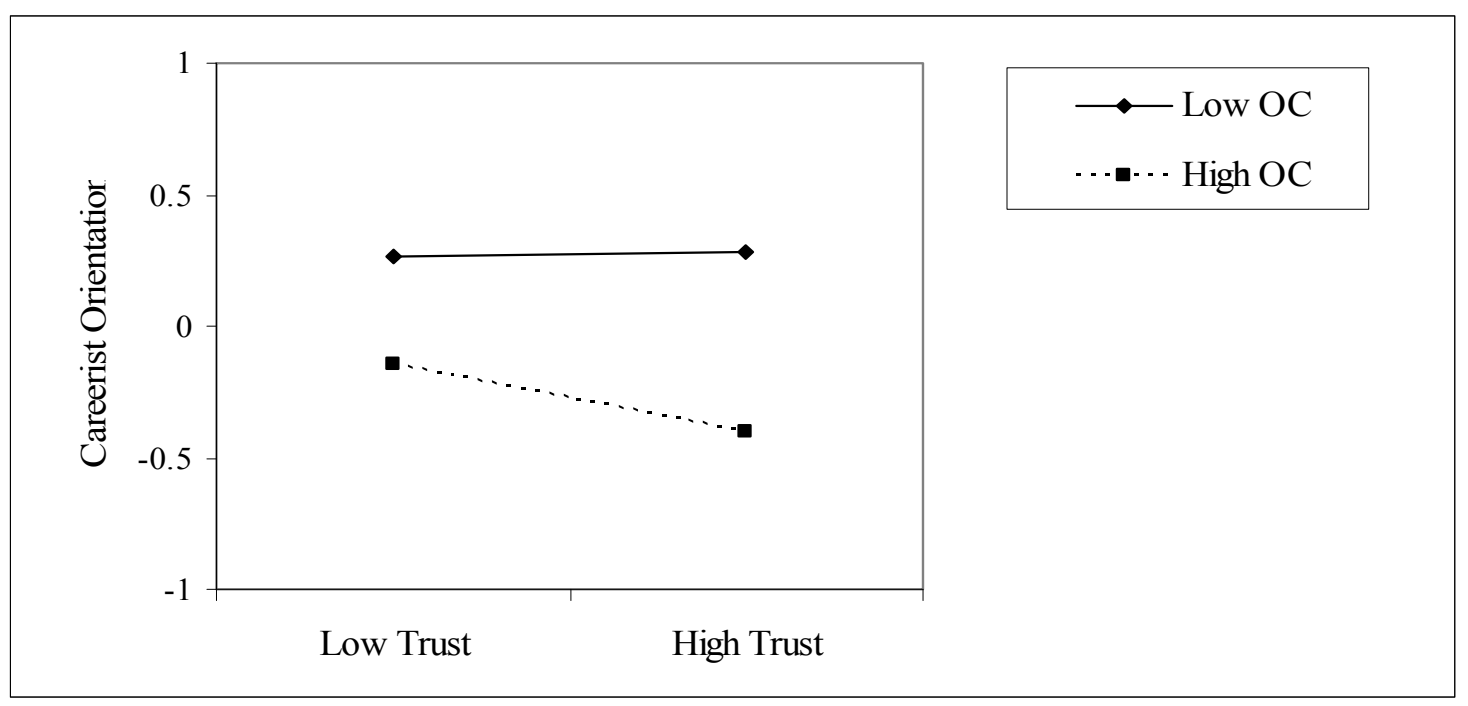

